Article

\title{
Hadron Therapy, Magnetic Nanoparticles and Hyperthermia: A Promising Combined Tool for Pancreatic Cancer Treatment
}

\author{
Francesca Brero ${ }^{1, *(\mathbb{D}}$, Martin Albino ${ }^{2}$, Antonio Antoccia ${ }^{3}$, Paolo Arosio 4 (D), \\ Matteo Avolio ${ }^{1}$, Francesco Berardinelli ${ }^{3}$, Daniela Bettega ${ }^{4}$, Paola Calzolari ${ }^{4}$, \\ Mario Ciocca ${ }^{5}$, Maurizio Corti ${ }^{1}$, Angelica Facoetti ${ }^{5}$, Salvatore Gallo ${ }^{4}$ (D, \\ Flavia Groppi ${ }^{6}$, Andrea Guerrini ${ }^{2}$ (D), Claudia Innocenti ${ }^{2,7}$ (D), \\ Cristina Lenardi ${ }^{4,8}{ }^{(D)}$, Silvia Locarno ${ }^{4}\left(\mathbb{D}\right.$, Simone Manenti ${ }^{6}{ }^{(D)}$, \\ Renato Marchesini ${ }^{4}$, Manuel Mariani ${ }^{1}$, Francesco Orsini 4 (D), \\ Emanuele Pignoli ${ }^{9}$, Claudio Sangregorio ${ }^{2,7,10}$, Ivan Veronese ${ }^{4}$ (D) \\ and Alessandro Lascialfari ${ }^{1, *}$
}

1 Dipartimento di Fisica and INFN, Università degli Studi di Pavia, 27100 Pavia, Italy; matteo.avolio01@universitadipavia.it (M.A.); maurizio.corti@unipv.it (M.C.); manuel.mariani@unipv.it (M.M.)

2 Dipartimento di Chimica, Università di Firenze and INSTM, 50019 Sesto Fiorentino (FI), Italy; martin.albino@unifi.it (M.A.); andrea.guerrini@sns.it (A.G.); claudia.innocenti@unifi.it (C.I.); claudio.sangregorio@iccom.cnr.it (C.S.)

3 Dipartimento di Scienze and INFN, Università Roma Tre, 00146 Roma, Italy; antonio.antoccia@uniroma3.it (A.A.); francesco.berardinelli@uniroma3.it (F.B.)

4 Dipartimento di Fisica and INFN, Università degli Studi di Milano, 20133 Milano, Italy; paolo.arosio@unimi.it (P.A.); daniela.bettega@mi.infn.it (D.B.); paola.calzolari@unimi.it (P.C.); salvatore.gallo@unimi.it (S.G.); cristina.lenardi@mi.infn.it (C.L.); silvia.locarno@unimi.it (S.L.); renato.marchesini@alice.it (R.M.); francesco.orsini@unimi.it (F.O.); ivan.veronese@unimi.it (I.V.)

5 Fondazione CNAO, 27100 Pavia, Italy; mario.ciocca@cnao.it (M.C.); angelica.facoetti@cnao.it (A.F.)

6 Dipartimento di Fisica, Università degli Studi di Milano and INFN, Lab. LASA, 20090 Segrate (MI), Italy; flavia.groppi@mi.infn.it (F.G.); simone.manenti@mi.infn.it (S.M.)

7 ICCOM-CNR, 50019 Sesto Fiorentino (FI), Italy

8 C.I.Ma.I.Na., Centro Interdisciplinare Materiali e Interfacce Nanostrutturati, 20133 Milano, Italy

9 Fondazione IRCSS Istituto Nazionale dei tumori, 20133 Milano, Italy; emanuele.pignoli@istitutotumori.mi.it

10 INFN, Sezione di Firenze, 50019 Sesto Fiorentino (FI), Italy

* Correspondence: francesca.brero01@universitadipavia.it (F.B.); alessandro.lascialfari@unipv.it (A.L.); Tel.: +39-0382-987-483 (F.B. \& A.L.)

Received: 31 August 2020; Accepted: 18 September 2020; Published: 25 September 2020

\begin{abstract}
A combination of carbon ions/photons irradiation and hyperthermia as a novel therapeutic approach for the in-vitro treatment of pancreatic cancer BxPC3 cells is presented. The radiation doses used are 0-2 Gy for carbon ions and 0-7 Gy for $6 \mathrm{MV}$ photons. Hyperthermia is realized via a standard heating bath, assisted by magnetic fluid hyperthermia (MFH) that utilizes magnetic nanoparticles (MNPs) exposed to an alternating magnetic field of amplitude 19.5 mTesla and frequency $109.8 \mathrm{kHz}$. Starting from $37^{\circ} \mathrm{C}$, the temperature is gradually increased and the sample is kept at $42{ }^{\circ} \mathrm{C}$ for $30 \mathrm{~min}$. For MFH, MNPs with a mean diameter of $19 \mathrm{~nm}$ and specific absorption rate of $110 \pm 30 \mathrm{~W} / \mathrm{g}_{\mathrm{Fe} 3} \mathrm{O}_{4}$ coated with a biocompatible ligand to ensure stability in physiological media are used. Irradiation diminishes the clonogenic survival at an extent that depends on the radiation type, and its decrease is amplified both by the MNPs cellular uptake and the hyperthermia protocol. Significant increases in DNA double-strand breaks at $6 \mathrm{~h}$ are observed in samples exposed to MNP uptake, treated with 0.75 Gy carbon-ion irradiation and hyperthermia. The proposed experimental protocol, based on the
\end{abstract}


combination of hadron irradiation and hyperthermia, represents a first step towards an innovative clinical option for pancreatic cancer.

Keywords: hadron therapy; magnetic nanoparticles; hyperthermia; nanomaterials; magnetic fluid hyperthermia; pancreatic cancer

\section{Introduction}

Pancreatic cancer is the seventh leading cause of cancer deaths [1], being responsible for $6 \%$ of all cancer-related deaths. Researchers are tirelessly endeavoring to develop therapies for pancreatic adenocarcinoma, but in spite of their efforts, survival rate remains poor and most patients have an unresectable tumor at the time of the diagnosis [2]. To overcome these limits, conventional radiotherapy, commonly carried out with X-ray beams has been applied in the context of neoadjuvant or adjuvant therapy concepts, but only modest results have been obtained both because pancreatic cancer is radioresistant and because of the radiosensitivity of normal tissues and organs surrounding the tumor [3-6]. Therefore, highly and inherently conformal radiation therapy techniques, e.g., hadron therapy (HT), present promising alternative treatment options. As an emerging approach, the combination of these new modalities with more conventional therapeutical protocols seems to offer a more efficient way to kill cancer tissues and/or to control or possibly inhibit the tumor progression [7-9].

Hadron therapy employs radiation beams consisting of charged particles, like protons, carbon and helium ions. HT offers some important advantages in comparison to X-ray radiotherapy: (i) the damage induced on the tumor tissues is generally higher; (ii) as a consequence of point (i), it allows the treatment of radioresistant tumors; (iii) the surrounding healthy cells are kept safe because most energy is deposited within the tumor site (Bragg peak), maximizing the cancer cells damage and (iv) the particle beam remains more collimated along the full path and, therefore, any side effects to the adjacent normal tissues can be further reduced [10].

Among therapies additional to irradiation, hyperthermia (Hyp) is clinically investigated for its efficacy [11-15]. The main reason is that the cancer cells are intrinsically sensitive to hyperthermia, because of the highly disorganized development of the tumor and the consequent blood perfusion distortion, which leads to low $\mathrm{pH}$ and hypoxia; such an environment may favor cell death by temperature increase [16,17]. On the contrary, healthy tissues are kept safe because they are rarely in conditions of hypoxia and high acidity. The local heating of tumor tissue has been historically realized in different ways, e.g., bath heating [18], microwave irradiation [19], radiofrequency waves [20], focused ultrasounds [21,22], capacitance hyperthermia [23], concentrated laser light [24], magnetic fluid hyperthermia (MFH) [25-34] and, more recently, innovative techniques resulting from the coupling of different types of hyperthermia (for example, magnetic and ultrasonic hyperthermia or magnetic hyperthermia and phototherapy $[35,36])$. In a relatively recent literature-based review, Peeken et al. [37] show the currently used hyperthermia techniques for heat delivery and temperature control, remarking the different modes of action of Hyp. From a different point of view, Datta et al. [38] reviewed the advantages of using multifunctional MNPs in local tumor MFH, and discussed their role as multimodal theranostic vectors.

MFH is used for thermoablation $\left(\mathrm{T}>50^{\circ} \mathrm{C}\right)$ or as mild hyperthermia $\left(40-45^{\circ} \mathrm{C}\right)$ and has a minimal invasivity. It is performed by injecting superparamagnetic nanoparticles directly into the tumor and subsequently exposing the patient to an alternating magnetic field (AMF) of a specific intensity $\mathrm{H}$ and frequency $f$. The Brezovich criterion [39] H.f $<4.85 \times 10^{8} \mathrm{Am}^{-1} \mathrm{~s}^{-1}$, although under discussion [23], is used to save patients' health. MFH has already been successfully applied to treat patients in specialized hospitals, and many studies evaluated its efficacy on animal models too [40-42]. For what concerns clinical cases, MagForce AG [43], a company specialized in nanocancer therapy for treatment of tumors, initiated in 1997 a more than decennial study on materials and treatment methods, finally receiving the 
European Conformity (CE) marking for its MFH system in 2010. To date, it can boast the treatment of more than 100 patients affected by different types of cancer, e.g., glioblastoma multiforme and prostate cancer, spreading the MFH protocol to German, Polish and, recently, US hospitals. It is worth noting that in all successful cases (life expectation increased until 1.5 times), MFH is applied in combination with photon radiation therapy and, when proper, chemotherapy. The material injected intratumorally consists of aminosilane-coated magnetic nanoparticles (MNPs) with an iron-oxide magnetite core of a diameter $\mathrm{d} \approx 12-15 \mathrm{~nm}$ and dispersed in an aqueous solution [44-47].

The patients underwent six semi-weekly hyperthermia sessions for $60 \mathrm{~min}$ : after the MNPs injection they were exposed to an alternating magnetic field $\left(f=100 \mathrm{kHz}, \mu_{0} \mathrm{H}=2.5 \sim 19\right.$ mTesla) combined with radiotherapy [48]. At the preclinical level, for instance MNPs were used for a case of glioblastoma multiforme on Wistar rats, using $\mu_{0} \mathrm{H}=20$ mTesla and $f=874 \mathrm{kHz}\left(40 \mathrm{~min}\right.$ at $\mathrm{T}=42{ }^{\circ} \mathrm{C}$ ) [49]. Here, as in many other in-vitro and in-vivo cases, the Brezovich limit is exceeded, thus allowing the release of more thermal energy [50-52]. Remarkably, in most preclinical cases, superparamagnetic particles based on a $\mathrm{Fe}_{3} \mathrm{O}_{4}$ or $\gamma-\mathrm{Fe}_{2} \mathrm{O}_{3}$ core with $\mathrm{d} \approx 20-22 \mathrm{~nm}$ are used, properly coated to prevent undesired aggregation and for ensuring biocompatibility [53,54].

In addition to X-ray radiotherapy plus MFH therapy, some cases of hyperthermia combined to HT have been recently reported. Datta et al. [55] report on two patients with unresectable soft-tissue sarcomas in the lower leg. They were treated with local hyperthermia (RF waves) once a week, in combination with a daily proton therapy (for 7 weeks), achieving functional limb preservation with nearly total tumor control. As a second example, Maeda et al. [56] suggested that hyperthermia (water bath at $\mathrm{T}=42.5^{\circ} \mathrm{C}$ for $1 \mathrm{~h}$ ), applied immediately after radiation exposure, might induce hypersensitization to hadron radiation (protons and carbon ions). Thirdly, Ahmad et al. [57] collected preliminary data on the sensitization of cells to proton therapy using A549 lung cancer cells subjected to hyperthermia treatment $\left(\mathrm{T}=42{ }^{\circ} \mathrm{C}\right.$ using a heating pad) and to proton irradiation. Their results showed that the cell survival fraction dropped on average by 10-15\% both at 2 and $4 \mathrm{~Gy}$.

As concerns the combined action of radiotherapy, MNPs and hyperthermia, it should be noted that their effect could be synergistic or additive, as is usual in cancer treatments by means of, e.g., radiotherapy combined with chemotherapy, immunotherapy, surgery, hyperthermia and so on. For example, Dong et al. [58] show the synergistic osteosarcoma therapeutic strategy when hyperthermia is combined with elaborately catalytic Fenton reaction achieved by $\mathrm{Fe}_{3} \mathrm{O}_{4}$ and $\mathrm{CaO}_{2} \mathrm{NPs}$. On the other hand, Ito et al. [59] for the treatment of HER2-overexpressing cancer reported the combination of antibody therapy with magnetic hyperthermia showing an additive effect. Thus, being that killing tumor cells is the main goal, both additive and/or synergistic effects have been shown to be able to reduce the survival of tumor cells.

Although sparse data related to radiotherapy plus Hyp are available in the literature, there is a clear lack of systematic studies regarding the possible combination of HT and Hyp where MFH is used for locally increasing temperature. The present work aims to address the lack of investigation in this direction, by presenting a novel and promising approach directed to pancreatic BxPC3 tumor cells treatment. With the use of HT plus Hyp and, for comparison, of X-ray irradiation plus Hyp, we show that the clonogenic survival of $\mathrm{BxPC} 3$ cell cultures, decreased at first by $\mathrm{HT}$, is further diminished by MNP uptake and Hyp treatment, the last one giving an additive killing effect of about $15-30 \%$ (MNPs action possibly being synergistic when photons are used). Moreover, when a 0.75 Gy carbon ions irradiation is used, we noted a significant increase in DNA double-strand-breaks at $6 \mathrm{~h}$ due to MNPs uptake and hyperthermia.

Our experimental results clearly remark the better efficacy of a dual-therapy treatment with respect to single therapy case and pave the way to translate the proposed protocol to clinic. 


\section{Materials and Methods}

\subsection{Synthesis and Characterization of Nanoparticles}

All the samples were prepared under inert atmosphere using commercially available reagents. Benzyl ether (99\%), oleic acid (OA, 90\%), oleylamine (OAM, $\geq 98 \%$ ), meso-2,3-Dimercaptosuccinic acid (DMSA), toluene (anhydrous, 99.8\%), dimethyl sulfoxide (anhydrous, $\geq 99.9 \%$ ) and sodium hydroxide ( $\mathrm{NaOH}, \geq 98 \%$, pellets) were purchased from Aldrich Chemical Co. Iron(III) acetylacetonate $99 \%$ $\left(\mathrm{Fe}(\mathrm{acac})_{3}\right)$ from Strem Chemicals Inc. Hydrochloric acid $(\mathrm{HCl}, \geq 37 \%)$ and absolute ethanol (EtOH) were purchased from Fluka. Ultrapure water was obtained from a Milli- ${ }^{\circledR}$ Synthesis system from Millipore, Temecula, CA, USA. All chemicals were used as received.

In brief, $\mathrm{Fe}(\mathrm{acac})_{3}(2.83 \mathrm{~g}, 8 \mathrm{mmol})$, OAM (8.56 g, $\left.32 \mathrm{mmol}\right)$, OA (9.04 g, $\left.32 \mathrm{mmol}\right)$ and benzyl ether $(80 \mathrm{~mL})$ were mixed and magnetically stirred under a flow of nitrogen in a $250 \mathrm{~mL}$ three-neck round-bottom flask for $15 \mathrm{~min}$. The resulting mixture was heated to reflux $\left(290^{\circ} \mathrm{C}\right)$ at $25^{\circ} \mathrm{C} / \mathrm{min}$ and kept at this temperature for 90 min under a blanket of nitrogen and vigorous stirring. The black-brown mixture was cooled at room temperature and ethanol $(60 \mathrm{~mL})$ was added, causing the precipitation of a black powder. The product was magnetically separated with a permanent magnet, washed several times with ethanol and finally redispersed in toluene.

Afterwards, $400 \mathrm{mg}$ were dispersed in toluene $(60 \mathrm{~mL})$, added to a solution of meso-2,3-dimercaptosuccinic acid DMSA (600 mg) in dimethyl sulfoxide (DMSO, $15 \mathrm{~mL}$ ), sonicated for $1 \mathrm{~h}$ and finally incubated at room temperature for $12 \mathrm{~h}$ in a rotating agitator. The precipitate was magnetically separated with a permanent magnet, washed several times first with DMSO and then with ethanol and finally redispersed in MilliQ water $(80 \mathrm{~mL})$. The suspension was then basified to pH 10 with sodium hydroxide and adjusted to pH 7.4 with hydrochloric acid to make it stable.

The physical characteristics of the MNPs (e.g., size distribution and zeta potential characterized using a dynamic light scattering (DLS) instrument (Malvern Zetasizer ZS, Malvern Instruments Ltd., Malvern, UK). The morphology of the MNPs was determined using transmission electron microscopy, TEM (CM12 PHILIPS Transmission Electron Microscope, 100 kV).

Powder X-ray diffraction (XRD) measurements were carried out using a Bruker D8 Advance diffractometer equipped with a $\mathrm{Cu} \mathrm{K} \alpha$ radiation $(\lambda=1.54178 \AA)$ and operating in $\theta-\theta$ Bragg Brentano geometry at $40 \mathrm{kV}$ and $40 \mathrm{~mA}$. Lattice parameters, a, and the mean crystallite diameters, $\mathrm{d}_{\mathrm{XRD}}$, were evaluated using the TOPAS ${ }^{\circledR}$ software (Bruker) using the method of the fundamental parameter approach considering a cubic space group $\mathrm{Fd}-3 \mathrm{~m}$. The surfactant percentage was determined by elemental analysis on carbon, hydrogen and nitrogen (CHN analysis) performed by a CHN-S Flash E1112 Thermofinnigan Elementary Analyzer.

Magnetic measurements were performed using a SQUID magnetometer (Quantum Design MPMS, San Diego, CA, USA) operating in the 2-350 K temperature range with applied fields up to $5 \mathrm{~T}$. The powder sample was hosted in Teflon tape and then pressed in a pellet to prevent preferential orientation of the nanocrystallites under the magnetic field. The obtained values of magnetization were normalized by the weight of ferrite present in the sample and expressed in $\mathrm{Am}^{2} / \mathrm{kg}$ of ferrite.

\subsection{Cell Culture}

BxPC3 cells were obtained from ICLC (Interlab Cell Line Collection, Genova, Italy). Cells were maintained at $37^{\circ} \mathrm{C}$ in a humidified atmosphere containing $5 \% \mathrm{CO}_{2}$ in air as exponentially growing cultures in RPMI 1640 media (Roswell Park Memorial Institute, Sigma-Aldrich, St. Louis, MO, USA) supplemented with 10\% fetal bovine serum (FBS, Sigma-Aldrich) and gentamicin (50 mg/mL; Sigma-Aldrich). In these conditions, the doubling time was $35 \pm 2 \mathrm{~h}$ and the plating efficiency (PE) was about 50\%. 


\subsection{Cell Toxicity}

To assess the effect of MNPs on cell proliferation, BxPC3 cells in the logarithmic growth phase were treated with MNPs at a different concentration for 24 and $48 \mathrm{~h}$ of incubation. Cell toxicity was assessed by the clonogenic survival quantified after two weeks and was around $50-60 \%$ for cells incubated with MNPs of $50 \mu \mathrm{g} / \mathrm{mL}$ (for further data see Tables S1 and S2). Cell toxicity measured by the Trypan Blue assay after $48 \mathrm{~h}$ was around $3 \%$ for the same concentration. Results obtained from the cell cycle analysis of cells treated with MNPs (50 and $100 \mu \mathrm{g} / \mathrm{mL}$ ) for $48 \mathrm{~h}$ have not shown alterations in the cell cycle phases (see Table S3).

\subsection{Cellular Uptake of MNPs}

To quantify the cellular uptake of MNPs (after $48 \mathrm{~h}$ of incubation at a concentration of $50 \mu \mathrm{g} / \mathrm{mL}$ ), elemental iron (Fe) was quantitatively measured by inductively coupled plasma optical emission spectrometry (ICP-OES) with iCAP 6200 Duo upgrade, Thermofisher. Digestion with nitric acid was carried out at room temperature $\left(\mathrm{T}=22^{\circ} \mathrm{C}\right.$ ). The mean uptake (computed by averaging the results of all the ICP measurements performed for different experiments) was about $20 \mathrm{pg}(\mathrm{Fe}) / \mathrm{cell}$ (see Table S4 for more details).

\subsection{Irradiation}

Cell irradiation with carbon ions was performed using the synchrotron-based clinical scanning beams (fixed horizontal beam line) at the Centro Nazionale di Adroterapia Oncologica (CNAO, Pavia). Since our cells must be placed in appropriate sample holders (that must respect the CNAO beamline geometry) and they deposit in the form of monolayers, to have a sufficient number of cells $\left(1.5 \times 10^{6}\right)$ and irradiate them with the same dose we chose T25 flasks (25 $\mathrm{cm}^{2}$ surface). The flasks were placed vertically inside a water phantom put at the isocenter on the treatment table, at a depth of $15 \mathrm{~cm}$, corresponding to the mid spread-out Bragg peak (SOBP). The SOBP $(6 \mathrm{~cm}$ width, from 12 to $18 \mathrm{~cm}$ depth in water) was achieved with active beam energy modulation, using 31 different energies (246-312 MeV/u, Linear energy transfer (LET) of about $45 \mathrm{keV} / \mu \mathrm{m})$. Samples were irradiated at different doses (0-2 Gy).

Photon beam irradiation of cell cultures (dose 0-7 Gy) was performed using a 6 MV linear accelerator (VARIAN Clinac 2100C, Varian Medical Systems, Palo Alto, CA, USA) at the Fondazione IRCCS Istituto Nazionale dei Tumori, Milano, Italy. The flasks containing the cells were irradiated using a vertical beam $20 \times 20 \mathrm{~cm}^{2}$ field, placing them horizontally at the isocenter in a water phantom at $5 \mathrm{~cm}$ depth.

\subsection{Clonogenic Assay}

The cells were plated in T25 flasks (about $6 \times 10^{5}$ cell/flask) and after two days some cell samples were incubated with MNPs $(50 \mu \mathrm{g} / \mathrm{mL})$ for $48 \mathrm{~h}$ at $37^{\circ} \mathrm{C}$. Afterwards, the cells were exposed to radiation types (photons and carbon ions) at different doses and hyperthermia treatment to the determination of cell survival. After irradiation the cells were detached from the flasks (using $0.25 \%$ trypsin_EDTA), counted and reseeded in five T25 flasks for each dose at a suitable cell concentration and incubated for 14 days. The cells were then fixed with ethanol and stained with $10 \%$ Giemsa solution and colonies consisting of more than 50 cells were scored as survivors. Surviving fractions relative to the untreated cell samples were determined.

\subsection{Double Strand Breaks Studies}

After irradiation and/or hyperthermic treatment a portion of the BxPC3 cells were seeded in slide flasks (Thermo Fischer Scientific, Waltham, MA, USA) with $3 \mathrm{~mL}$ fresh medium and collected 6 and $24 \mathrm{~h}$ later. Cells were fixed in $4 \%$ paraformaldehyde (PFA), permeabilized with $0.2 \%$ Triton $\mathrm{X}-100$ and blocked at $37^{\circ} \mathrm{C}$ in BSA $1 \%(w / v)$ dissolved in phosphate-buffered saline (PBS). Samples 
were then coimmunostained overnight $(\mathrm{ON})$ at $4{ }^{\circ} \mathrm{C}$, using a rabbit polyclonal anti-53BP1 antibody (Novus Biologicals, Littleton, CO, USA) in combination with a mouse monoclonal anti- $\gamma \mathrm{H} 2 \mathrm{AX}$ antibody (Millipore, Temecula, CA, USA). After washes in PBS/BSA 1\% samples were incubated for $1 \mathrm{~h}$ at $37^{\circ} \mathrm{C}$ in the secondary Alexa 546 anti-mouse and Alexa 488 anti-rabbit antibodies (Invitrogen, Life Technologies, Carlsbad, CA, USA). Finally, slides were washed in PBS/BSA 1\%, counterstained with DAPI (Sigma-Aldrich, St. Louis, MO, USA) and mounted using the fluorescent mounting medium Vectashiled (Vector Laboratories, Burlingame, CA, USA). Images were acquired with an Axio-Imager.M1 fluorescent microscope (Zeiss, Jena, Germany) and analyzed using ISIS software (Metasystems, Milano, Italy). The frequency of both the DNA damage marker foci per cell were scored in 100 nuclei in four independent experiments.

\subsection{Magnetic Fluid Hyperthermia Setup}

Magnetic hyperthermia experiments were performed using a MagneTherm ${ }^{\mathrm{TM}}$ set-up by Nanotherics, working at $109.8 \mathrm{kHz}$ and amplitude $19.5 \mathrm{mTesla}$. The temperature of the samples was measured using an Optocon ${ }^{\mathrm{TM}}$ optical fiber thermometer positioned at the centre of the sample placed inside an Eppendorf PCR Tube (also called mini-Eppendorf). The sample holder was optimized to accommodate two Eppendorf Tubes (volume $0.2 \mathrm{~mL}$ ). In fact, the temperature was detected in a "twin-sentinel" sample, placed next to the sample used for the clonogenic assay, since it is necessary, for survival studies, to keep the latter sterile. It should be remarked that, due to the necessary heat insulation and coil geometry (inner diameter $44 \mathrm{~mm}$ ), and thus to very limited space, we were forced to use Eppendorf tubes in place of much bigger T25 flasks (and thus a pelletization process that followed the irradiation, to transfer the samples from T25 flasks to mini-Eppendorf, see below).

\subsection{Magnetic Hyperthermia Treatment}

For the hyperthermia treatments the irradiated cells with MNPs were trypsinized, centrifuged (1500 rpm for $10 \mathrm{~min}$ ), the cellular pellets (about $1.5 \times 10^{6}$ cells in $0.1 \mathrm{~mL}$ medium) were transferred

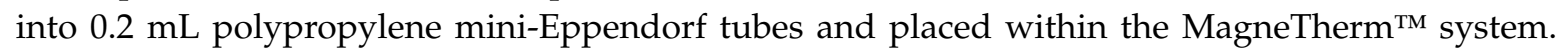
The pelletizing effect, obligatory step to switch from the irradiation configuration (cells in flasks) to that used for hyperthermic treatment (cells in mini-Eppendorf tubes), responsible of an ulterior stress for the cells was taken into account and separated from MFH action in the reported clonogenic survival curves (see paragraph 3.2). This stress is due to all the operations (trypsinization, centrifugation and vortexing) necessary to transfer the irradiated cells from the T25 flask to the mini-Eppendorf. This stress is quantified by a reduced plating efficiency caused by cells that are damaged and therefore no longer proliferate or proliferate less; this effect was taken into account in renormalizing the clonogenic survival curves. When the evaluation of survival rate is given, the eventual stress effect was previously subtracted. A custom thermalization system, based on a Lauda Alpha A thermostat, and a polystyrene sample holder, was placed inside the MagneTherm ${ }^{\mathrm{TM}}$ coil to stabilize the initial temperature of the sample to the physiological value of $37^{\circ} \mathrm{C}$, to center the sample in the homogeneity region of the field and to minimize heat dissipation. An AMF (amplitude $\mu_{0} \mathrm{H}=19.5 \mathrm{mTesla}$ and frequency $f=109.8 \mathrm{kHz}$ ) was applied immediately after the irradiation to increase the temperature of the cells up to $42{ }^{\circ} \mathrm{C}$; this temperature was later maintained for $30 \mathrm{~min}$ by changing the temperature of the water circulating within the thermalization system. The field and frequency values have been selected not to exceed Brezovich's criterion excessively, as these values reflect those used in the clinic [43].

\section{Results and Discussion}

\subsection{Synthesis and Characterization of MNPS}

Since experiments lasted more than 3 years, it was not possible to use the same batch of MNPs. Different batches of MNPs with similar features were then prepared following the same procedure. The characteristics of a representative sample are described in the following. The samples consisted of 
a spherical $\mathrm{Fe}_{3} \mathrm{O}_{4}$ core coated with meso-2,3-dimercaptosuccinic acid. The MNPs were synthesized by thermal decomposition of iron acetylacetonate $\left(\mathrm{Fe}(\mathrm{acac})_{3}\right)$, in benzyl ether in the presence of oleic acid (OA) and oleylamine (OAM) as surfactants.

The core morphodimensional characteristics were studied by means of transmission electron microscopy (TEM), using a CM12 PHILIPS transmission electron microscope. In Figure 1a we report a representative TEM image, which demonstrates the almost spherical shape of the particles; a mean core diameter value of $\mathrm{d}_{\text {TEM }}=19.2 \pm 3.6 \mathrm{~nm}$ was extracted from the histogram of the size distribution.

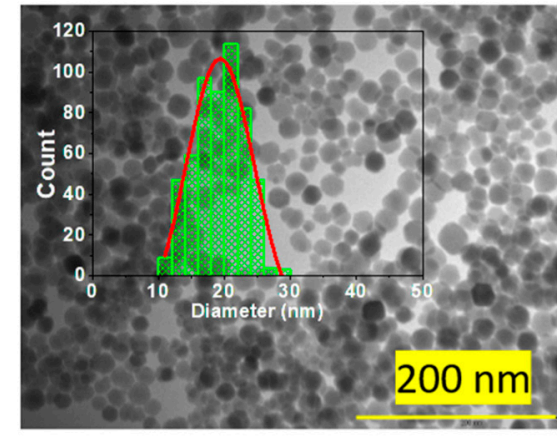

a

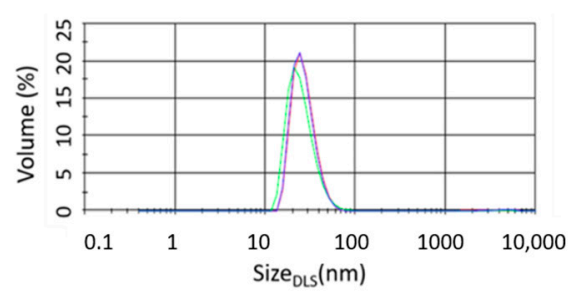

$\mathbf{b}$

Figure 1. (a) Representative bright-field TEM image, together with the histogram of the size distribution $\left(\mathrm{d}_{\text {TEM }}=19.2 \pm 3.6 \mathrm{~nm}\right)$. The solid red line represents the best Gaussian fit. (b) Dynamic light scattering (DLS) diameter $\mathrm{d}_{\mathrm{DLS}}$ measurements at $\mathrm{pH}$ 7.4. The green, blue and red lines represent data obtained from three different measurements.

The X-ray diffraction pattern (see Supplementary Materials Figure S1) shows a single crystalline phase with a diffraction pattern compatible with the inverse spinel cubic structure characteristic of magnetite. The peaks all match the reference pattern (JCPDS 19-0629) as regards both position and intensity. The lattice parameter $(\mathrm{a}=8.387 \AA)$ is close to the one expected for magnetite $(8.396 \AA)$, suggesting a low degree of surface oxidation of the MNPs, which reasonably consist of a magnetite core surrounded by a thin maghemite shell. The crystallite diameter obtained by the Scherrer analysis $\left(\mathrm{d}_{\mathrm{XRD}}=18.7 \pm 0.4 \mathrm{~nm}\right)$ is comparable to the one obtained by TEM measurement, suggesting that the MNPs are single crystals and present a high degree of crystallinity.

The MNPs were dispersed in $\mathrm{pH} 7.4$ water after coating with DMSA (ca. $2 \% w / w$ as evaluated by $\mathrm{CHN}$ analysis). The successful DMSA functionalization and the stability in water solution were also confirmed by dynamic light scattering (DLS, Figure 1b) and zeta potential (Figure S2) measurements, which provided $\mathrm{d}_{\mathrm{DLS}}=27 \pm 8 \mathrm{~nm}$ and $\mathrm{Z}=-30.5 \pm 7.5 \mathrm{mV}$ at $\mathrm{pH} 7.4$.

The hyperthermic efficiency was estimated by evaluating the specific absorption rate (SAR). The SAR of the samples was calculated using the following formula: [60]

$$
S A R=\frac{m_{\mathrm{H}_{2} \mathrm{O}} c_{\mathrm{H}_{2} \mathrm{O}}+m_{\mathrm{Fe}_{3} \mathrm{O}_{4}} c_{\mathrm{Fe}_{3} \mathrm{O}_{4}}}{m_{\mathrm{Fe}_{3} \mathrm{O}_{4}}} \cdot \frac{\Delta T}{\Delta t}
$$

where $c_{\mathrm{H}_{2} \mathrm{O}}=4.18 \mathrm{~J} \mathrm{~K}^{-1} \mathrm{~g}^{-1}$ and $c_{\mathrm{Fe}_{3} \mathrm{O}_{4}}=0.62 \mathrm{~J} \mathrm{~K}^{-1} \mathrm{~g}^{-1}$ are the specific heat of water and magnetite in colloidal solutions, while $m_{\mathrm{H} 2 \mathrm{O}}$ and $m_{\mathrm{Fe} 3 \mathrm{O} 4}$ are the respective masses. We neglected the contribution of the DMSA coating because of its small mass fraction. From the experimental temperature kinetics curve, $T$ vs $t$, the SAR was estimated to be $110 \pm 30 \mathrm{~W} / \mathrm{g}_{\mathrm{Fe} 3 \mathrm{O} 4}$ under an AMF of frequency $f=109.8 \mathrm{kHz}$ and amplitude $\mu_{0} \mathrm{H}=19.5$ mTesla (for more details see Figure S3).

The field dependence of the sample magnetization was investigated by means of SQUID magnetometry. In Figure 2 we reported the $\mathrm{M}$ vs. $\mathrm{H}$ curves obtained at $5 \mathrm{~K}$ and $300 \mathrm{~K}$. 


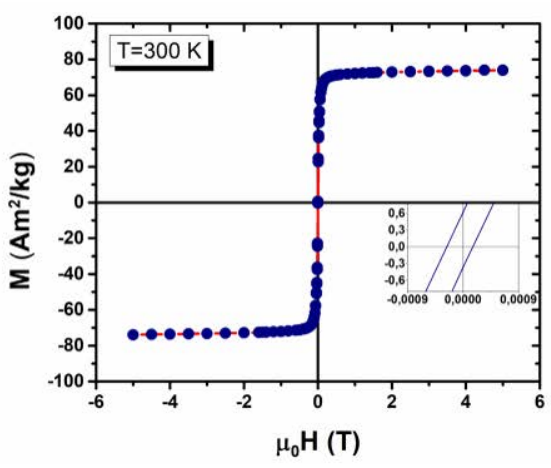

a

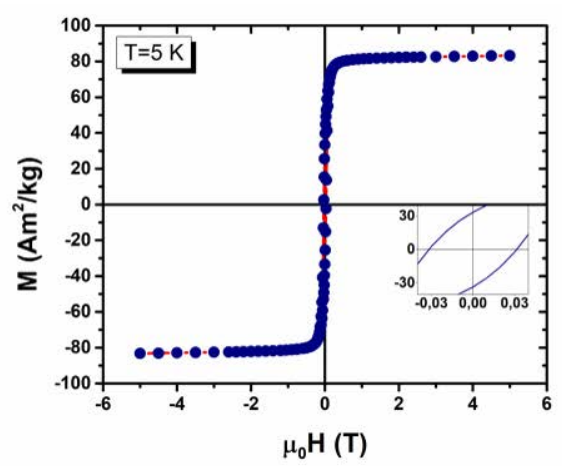

b

Figure 2. (a) Hysteresis loop measured at $300 \mathrm{~K}$ and (b) $5 \mathrm{~K}$, in the field range \pm 5 Tesla. In the insets, we report the low field regions.

At $\mathrm{T}=5 \mathrm{~K}$ MNPs showed hysteretic behavior with a coercive field $\mu_{0} \mathrm{Hc}=30 \pm 2 \mathrm{mTesla}$, while a negligible opening-up of the hysteresis loop was observed at $\mathrm{T}=300 \mathrm{~K}$ (less than $0.3 \mathrm{mTesla}$, comparable to the remanent field). These results indicate that MNPs display a superparamagnetic behavior, as expected for magnetite based MNPs of this size. At both temperatures, the saturation magnetization, Ms, was very high $\left(83 \mathrm{Am}^{2} / \mathrm{kg}\right.$ at $5 \mathrm{~K}$ and $74 \mathrm{Am}^{2} / \mathrm{kg}$ at $300 \mathrm{~K}$ ) and close to the bulk values (91.7 $\mathrm{Am}^{2} / \mathrm{kg}_{\mathrm{Fe} 3 \mathrm{O} 4}$ at room temperature [61]), confirming the high crystallinity of the inorganic core.

\subsection{Experimental Treatment Protocol}

As a novel cancer treatment, we investigated the possible synergistic/additive action of hadron therapy and hyperthermia on pancreatic cancer BxPC3 cell culture. The general experimental protocol, sketched in Scheme 1, comprised of three different treatment modes, indicated as 1, 2 and 3 (see next paragraph and Materials and Methods for more details).

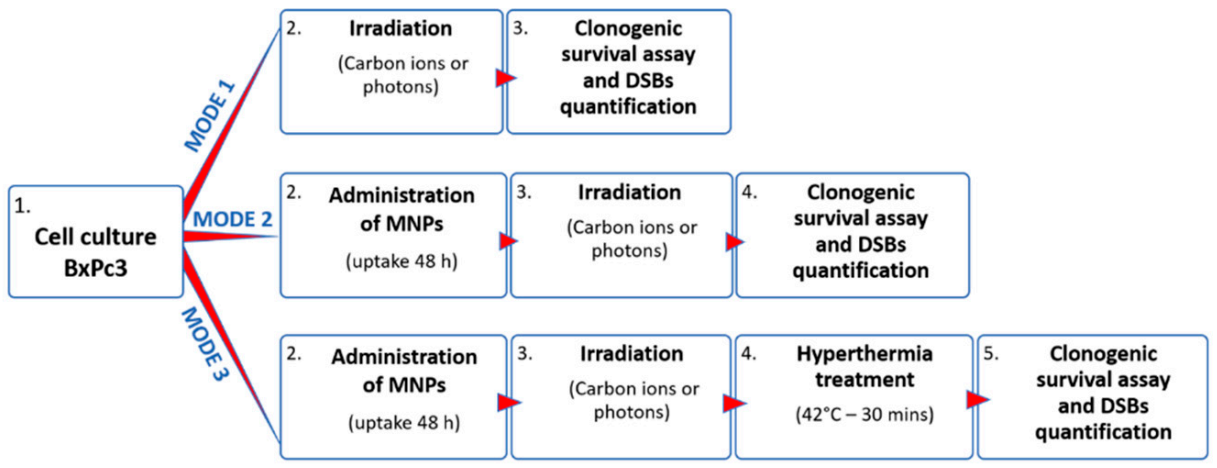

Scheme 1. Description of the 3 different treatment modes used during the experiments. Clonogenic survival has been determined after simple irradiation (mode 1), magnetic nanoparticles (MNPs) administration and irradiation (mode 2) and MNPs administration plus irradiation and subsequent hyperthermia (Hyp; mode 3). DSB stands for a break in double-stranded DNA in which both strands have been cleaved.

The irradiation of samples (cells incubating or not MNPs) have been performed by a C ions beam at the synchrotron-based facility at the National Center for Oncological Hadron Therapy (CNAO) in Pavia, or by means of photons, using a $6 \mathrm{MV}$ linear accelerator at the Fondazione IRCCS Istituto Nazionale dei Tumori in Milano (INT).

The MNPs, used to perform part of the hyperthermic process via MFH, have been administered to human pancreatic adenocarcinoma BxPC3 cells with a concentration $50 \mu \mathrm{g} / \mathrm{mL}$ in the culture medium. 
The cells were incubated for $48 \mathrm{~h}$ to favor cells' uptake (see Materials and Methods) and thus improve the MFH efficacy.

In the cases of combined therapy (mode 3 in Scheme 1), after the irradiation, we applied Hyp to samples of cells incubating MNPs. The temperature was increased from $37^{\circ} \mathrm{C}$ to $42{ }^{\circ} \mathrm{C}\left(\Delta \mathrm{T}=5^{\circ} \mathrm{C}\right)$ and then kept constant for $30 \mathrm{~min}$, by means of bath heating (through a thermalization system that circulates water around the sample) and MFH, realized by an AMF of 19.5 mTesla amplitude and $109.8 \mathrm{kHz}$ frequency. A sketch of the hyperthermia setup is shown in Figure 3. The amount of uptaken MNPs was estimated by inductively coupled plasma-optical emission spectrometry (ICP-OES) and found on average $\sim 20 \mathrm{pg}(\mathrm{Fe}) / \mathrm{cell}$, calculated over different experiments. With this amount, on average about $40 \%$ of the heating is due to the application of the magnetic field, while the remaining temperature increase was obtained due to the thermalization system. It should be noted that, due to the small cell volume, the value of $20 \mathrm{pg}(\mathrm{Fe}) / \mathrm{cell}$ corresponded to filling mostly the inner part and the surface of the cell and, thus, a quantity of heat release near to the highest one.

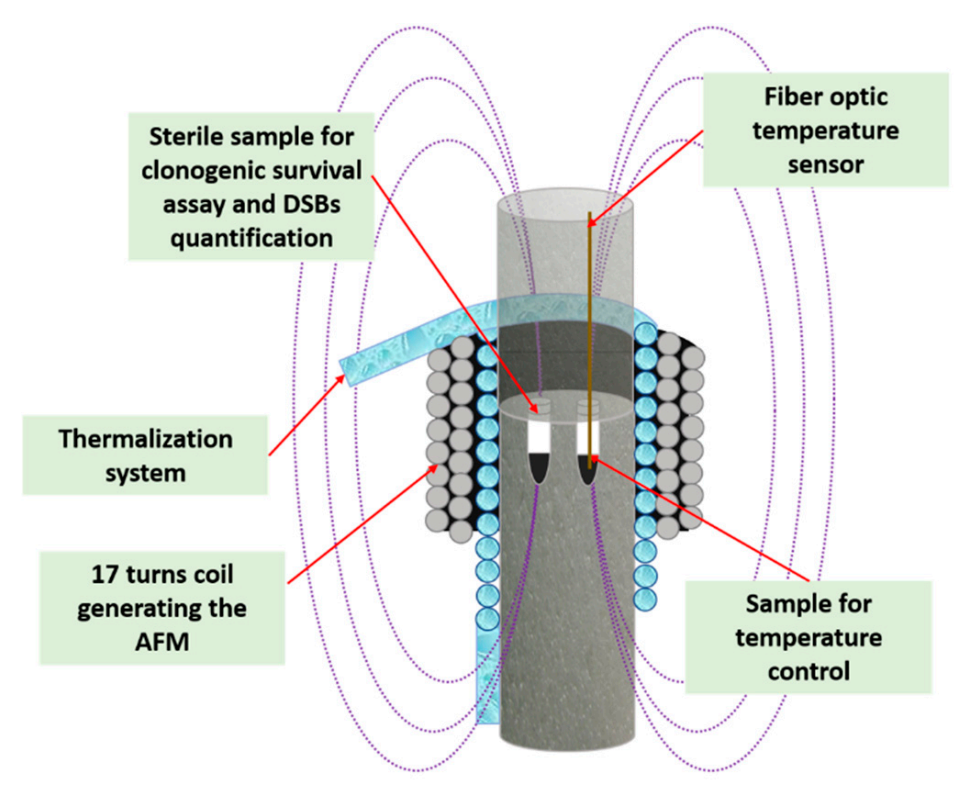

Figure 3. Representation of the hyperthermia setup. A thermalization system (bath heating) circulates water around the two sample vials, one sterile for the clonogenic survival assay and DSBs detection, and one for the temperature registration by a fiber optic probe.

The biological effect of the different treatment modes was finally assessed:

(i) By using a clonogenic assay after two weeks. The clonogenic cell survival assay, i.e., the ability of a cell to produce a viable colony containing at least 50 cells, is considered as a gold standard method for studying cellular sensitivity to irradiation [62];

(ii) By estimating the number of non-repairable double strand breaks (DSBs) per cell after 6 and $24 \mathrm{~h}$, through detection and counting of persistent repair foci, which are DSBs markers. This study was limited to carbon ions irradiation.

\subsection{Clonogenic Survival Studies}

\subsubsection{Carbon Ion Irradiation Experiments}

At first, the assessment of the effect of the combination of HT + MNPs + Hyp was performed using the clonogenic assay 2 weeks after the experiment. Figure 4 shows survival data of BxPC 3 cells treated with three different modes as described in Scheme 1: (1) only carbon ion (0-2 Gy) irradiation (HT, orange circles); (2) carbon ion irradiation after the administration of magnetic nanoparticles 
(HT + MNP, navy triangles) and (3) carbon ion irradiation on culture cells containing MNPs combined with the hyperthermia treatment for $30 \mathrm{~min}$ at $42{ }^{\circ} \mathrm{C}$ ( $\mathrm{HT}+\mathrm{MNP}+$ Hyp, green stars).

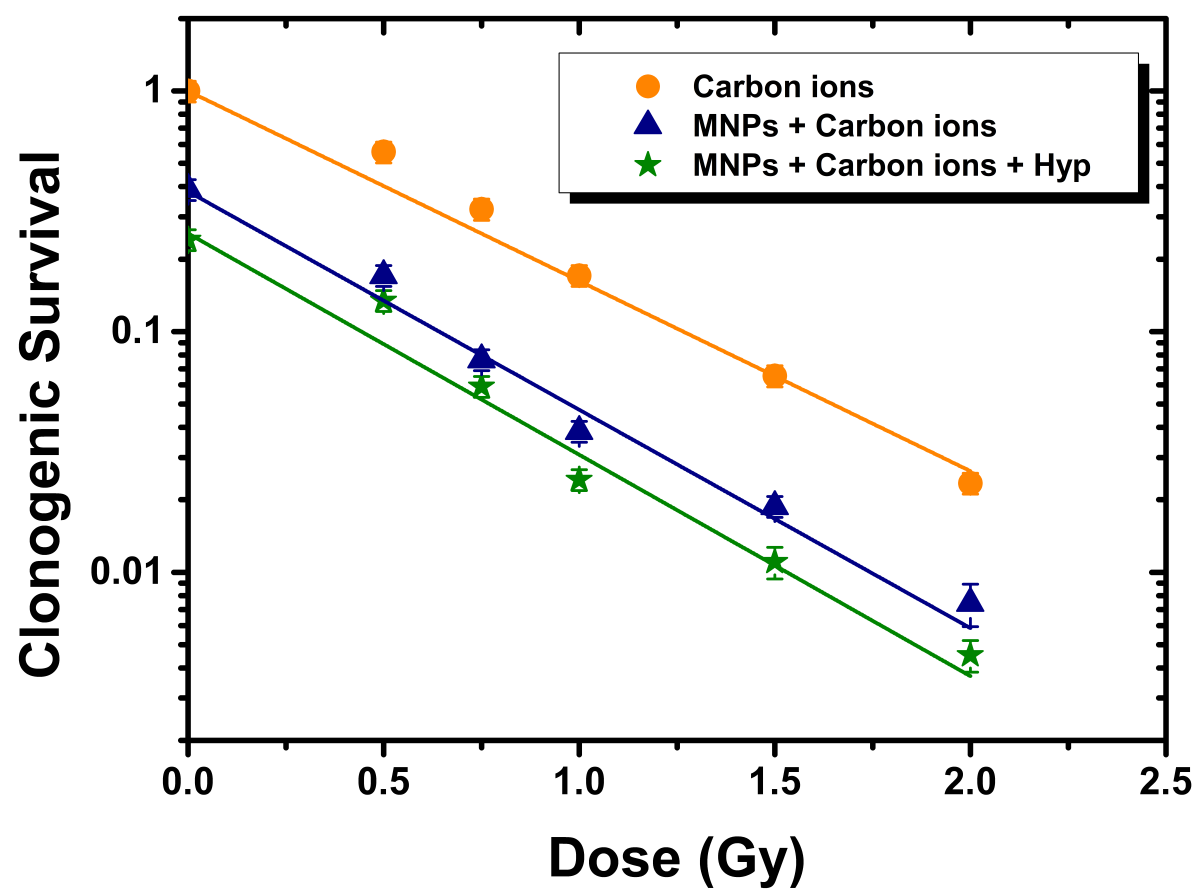

Figure 4. Clonogenic survival of BxPC3 cells culture for 3 different protocols (see text): hadron therapy (HT) only (orange circles), HT + MNPs administration (navy triangles) and HT + MNPs administration + Hyp (green stars). An additive effect of MNPs and Hyp is noted. Solid lines represent the best fit of the clonogenic survival (CS) curves as a function of the radiation dose $\mathrm{D}$ according to the law $\mathrm{CS} \propto \exp (-\alpha \mathrm{D})$. From the fits: $\alpha_{\mathrm{C} \text { ions }}=1.82 \pm 0.06 \mathrm{~Gy}^{-1} ; \alpha_{\mathrm{MNPs}+\mathrm{C} \text { ions }}=2.09 \pm 0.15 \mathrm{~Gy}^{-1}$ and $\alpha_{\mathrm{MNPs}+\mathrm{C} \text { ions }+\mathrm{Hyp}}=2.11 \pm 0.20 \mathrm{~Gy}^{-1}$.

The results for each protocol were averaged over four independent experiments.

The following observations were found:

(i) At 0 Gy dose, i.e., unirradiated samples, clonogenic survival (CS) decreased from 1 to $0.4 \pm 0.04$ when MNPs were added, due to a MNP toxicity at 15 days. A further decrease of CS to $0.24 \pm 0.02$ was observed when also Hyp was applied (mode 3);

(ii) If carbon ions irradiation alone was applied, the CS decreased on increasing the dose, according to the law: $C S \propto \exp (-\alpha \mathrm{D})$ where $\mathrm{D}$ is the dose;

(iii) At all doses, once MNPs were added and irradiation was performed (mode 2), a decrease of CS with respect to irradiation only (mode 1) was observed;

(iv) At all doses, once Hyp was further added (mode 3), the CS dropped further.

It is thus straightforward to conclude that: (i) there is a sizeable MNP toxicity that could result in a potential additive therapeutic effect (although not synergistic) and (ii) hyperthermia grants an additional killing effect on tumor cells with respect to hadron therapy alone.

\subsubsection{Photon Irradiation Experiments}

To compare the effect of HT plus Hyp treatment with a more conventional one making use of photon irradiation plus Hyp, we performed experiments by using a linear particle accelerator Linac at INT. Figure 5 shows survival data of BxPC 3 cells exposed to different doses of 6 MV photons (0-7 Gy) and to Hyp at $42{ }^{\circ} \mathrm{C}$ for $30 \mathrm{~min}$, as averaged over two independent experiments. 


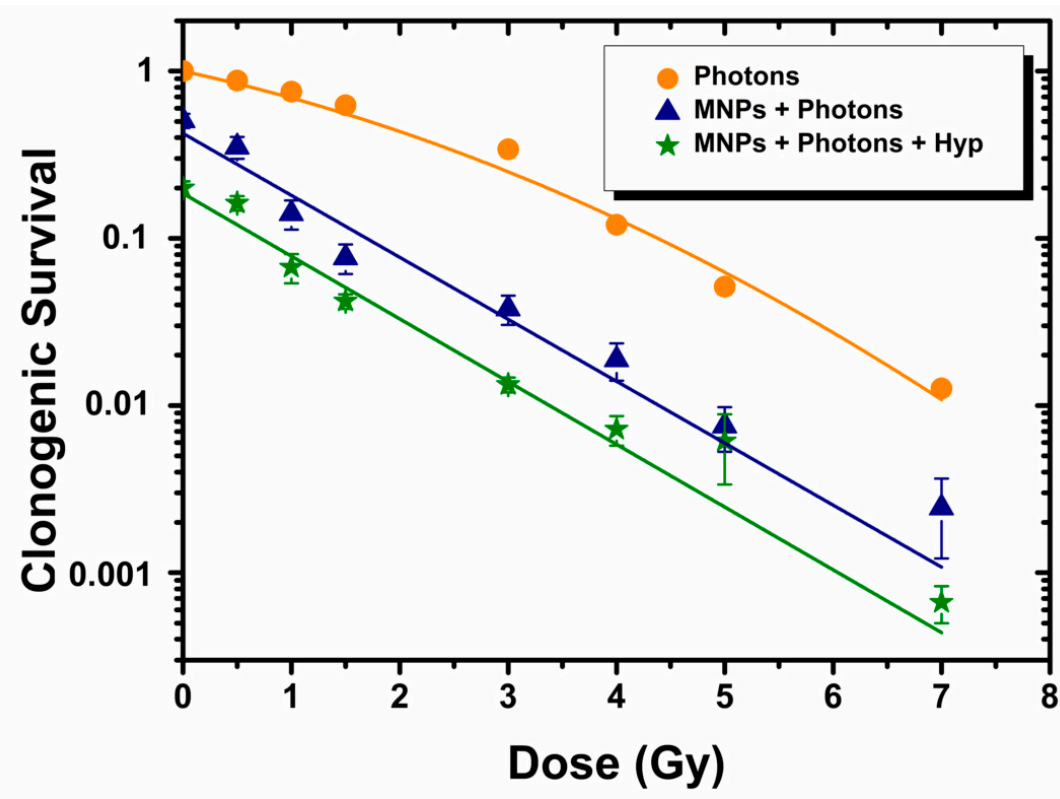

Figure 5. Clonogenic survival of BxPC3 cells incubated with or without MNPs, irradiated with photons (0-7 Gy) and combined (or not) with Hyp. Solid lines represent the best fit of the clonogenic survival (CS) curve as a function of the radiation dose $D$ according to the law $C S \propto \exp \left(-\alpha D-\beta D^{2}\right)$ for photons alone, and to $C S \propto \exp (-\alpha \mathrm{D})$ for the other two treatments. From the fit: $\alpha_{\text {Photons }}=0.32 \pm 0.06 \mathrm{~Gy}^{-1}$; $\beta_{\text {Photons }}=0.05 \pm 0.01 \mathrm{~Gy}^{-2} ; \alpha_{\mathrm{MNPs}}+$ Photons $=0.85 \pm 0.09 \mathrm{~Gy}^{-1}$ and $\alpha_{\mathrm{MNPs}+\text { Photons }+\mathrm{Hyp}}=0.86 \pm 0.06 \mathrm{~Gy}^{-1}$.

In a similar way to the CNAO experiments, three treatment modes were used: (i) photon irradiation alone (orange circles), (ii) photon irradiation after the administration of MNPs for $48 \mathrm{~h}$ (navy triangles) and (iii) photon irradiation on cells incubating MNPs combined to $30 \mathrm{~min}$ at $42{ }^{\circ} \mathrm{C}$ Hyp treatment (green stars).

One could observe the following:

(i) As in the HT case, at 0 Gy dose, i.e., unirradiated samples, clonogenic survival (CS) decreased from 1 to $0.5 \pm 0.05$ when MNPs were added, and a further decrease of CS to $0.2 \pm 0.02$ was observed when also Hyp was applied (mode 3);

(ii) If only photon irradiation was applied, the CS decreased once the dose was increased according to the linear quadratic model: $C S \propto \exp \left(-\alpha \mathrm{D}-\beta \mathrm{D}^{2}\right)$;

(iii) At all doses, CS decreased once MNPs were added with respect to irradiation with photons only, confirming the results found for HT;

(iv) When MNPs were added, the CS vs. D model changed to $C S \propto \exp (-\alpha \mathrm{D})$, which corresponded to a modification of the cells response to photon irradiation; thus the typical shoulder of the dose-survival curves, found after treatment with radiation alone, was removed;

(v) As in HT, once Hyp was further added, the CS dropped further; also in this case, the dose-survival curve obeyed the law $C S \propto \exp (-\alpha \mathrm{D})$.

Therefore, also in this case we could conclude that: (i) there was a MNP toxicity, comparable to the HT case, and (ii) Hyp gave an additive killing effect on tumor cells with respect to photon irradiation alone.

Let us compare shortly the results of carbon ions and photon irradiation alone. As already observed for other type of tumors [63-65] and other pancreatic tumor cell lines [51], also in the case of BxPC3 cells the survival fractions obtained when carbon ion radiotherapy was used were lower than those for the photon-irradiated samples. This means that carbon ion radiotherapy shows an enhanced efficacy as compared to standard photon radiotherapy. Moreover, as mentioned in the introduction, due to the physical characteristics of high-LET particle radiation (carbon ions) the maximum dose 
deposition occurs at the so-called Bragg Peak, the depth of which can be adjusted at will within the target tissue. Based on this custom dose profile it should be possible to more accurately administer maximum doses to the tumor with minimum adverse effects to the surrounding tissues. For carbon ion and photon irradiations $\alpha$ values were determined and are given in the captions of Figures 4 and 5 . As expected, $\alpha$ values were significantly higher for carbon ions than for photons, reflecting a steeper decline of the initial slope of the survival curves for high-LET beams.

Remarkably, particle radiation has been proven to have a higher relative biological effectiveness (RBE) achieving an increased cytotoxic effect when compared with conventional photon therapy. Additionally, we determined the carbon ions RBE by comparing cell survival data after carbon and photon irradiations as the ratio between the dose of reference radiation ( $6 \mathrm{MeV}$ photon) and the carbon ions are necessary to produce the same biological effect.

At $10 \%$ of the clonogenic survival, the RBE of the CNAO carbon ions beam was equal to about 3.5. This result suggests that the use of hadrons in cancer therapy for the treatment of pancreatic tumors could be a promising modality. Until now the carbon ions RBE values reported in the literature are few, but they seem to agree with our result. El Shafie et al. [66] have found that the RBE of carbon ion irradiation for the BxPC3 cell line ranged from 1.5 to 3.5, depending on the survival level and dose, and data published by Oonishi and colleagues confirms, for the same cell line, the increased RBE of carbon ions irradiation [67].

Remarkably, as the MNPs presence increased the cell mortality rate and, in the case of photons, changed the dose-survival response law, we guess that they have a radiosensitizing (possibly synergistic) effect on BxPC3 cells. Similar results were obtained by Li et al. [68], Liu et al. [69] and Wang et al. [70] with gold nanoparticles and X-rays on 4T1, EMT-6 murine breast carcinoma and HeLa cells, respectively. In another perspective, Goel et al. [71] report progress in nanoparticles-mediated radiosensitization.

\subsection{Double Strand Breaks Studies for HT}

As a measure of the single/combined effect of hyperthermia and carbon ions irradiations in the induction of DNA damage, the kinetics of DNA double strand breaks rejoining has been evaluated by means of $\gamma \mathrm{H} 2 \mathrm{AX}$ and 53BP1 foci formation by immunofluorescence analysis. Both $\gamma \mathrm{H} 2 \mathrm{AX}$ (phosphorylation at Ser-139) and 53BP1 are well validated markers of DNA double-strand breaks. [72,73].

Results from four experiments carried out at the CNAO facility were collected and analyzed after exposure of BxPC3 pancreatic tumor cells to 0.75 and $1.5 \mathrm{~Gy}$ and harvested at 6 and $24 \mathrm{~h}$ from the three different treatment modes. In Figure 6 we report the normalized "foci/cell" values at different doses. It is observed: (i) as expected carbon ions radiation alone (mode 1) increased the number of DSBs with respect to control, i.e., untreated, samples (control, Figure 6a); such a difference was more pronounced at $6 \mathrm{~h}$ from treatment, indicating that at $24 \mathrm{~h}$ cell repair is more efficient for both DSBs markers used; (ii) at a zero dose, hyperthermia treatment (mode 3) further increased the number of DSBs at $6 \mathrm{~h}$ compared to samples without Hyp (mode 1 and 2 treatments, Figure 6b); (iii) at 0.75 Gy, Hyp induced a significant increase in DSBs after $6 \mathrm{~h}$, for both $\gamma \mathrm{H} 2 \mathrm{AX}$ and 53BP1 foci, while at $1.5 \mathrm{~Gy}$ the differences in the DSBs number between the three different treatment modes was minimal and (iv) at $24 \mathrm{~h}$ there were lower DSB values for both doses and for all treatment modes.

These results were similar to those reported by Ma et al. [74] and suggest that the MNPs+Hyp has a radiosensitization effect and inhibits cellular DNA repair mechanisms.

Although the available literature supports the notion that the hyperthermic effect is dependent on the LET of ionizing radiation, the potential molecular mechanism underlying hyperthermia radiosensitization for particle radiation still remain scantly investigated and poorly known. As for low-LET radiations, a major contribution in the untangling of such a mechanism $/ \mathrm{s}$ was provided by using Chinese hamster ovary $(\mathrm{CHO})$ cell lines specifically defective in the two processes devoted to the repair of radiation-induced DNA DSBs, and namely non homologous end joining (NHEJ) and homologous recombination (HR). In this respect, exposing $\mathrm{CHO}$ wild-type cells and a panel of repair defective counterparts to protons (LET $=1 \mathrm{keV} / \mu \mathrm{m} 42.5^{\circ} \mathrm{C}$ water bath, $1 \mathrm{~h}$ ) and carbon 
ions (LET $=13-70 \mathrm{keV} / \mu \mathrm{m} ; 42.5^{\circ} \mathrm{C}$ water bath, $1 \mathrm{~h}$ ) it was demonstrated a prevalent contribution of $\mathrm{HR}$ over NHEJ in radiosensitization, probably affecting the processing of a subset of DNA DSBs lesions [56]. Interestingly, at the molecular level it was shown that $\operatorname{Hyp}\left(\mathrm{T}>41^{\circ} \mathrm{C}\right)$ did inhibit $\mathrm{HR}$ in human and mouse cells, affecting some of the key players in this process (e.g., delaying recruitment of RAD51 at radiation-induced foci, degrading BRCA2, inactivating RPA, reducing the level of MRN complex, etc.; see [75]). In addition, since heat may explicate the pleiotropic effect on cells, it is generally thought that cytotoxic or sensitizing effects of Hyp cannot be attributed to deactivation of a single DNA repair mechanism, but rather to influencing many pathways (e.g., cell cycle progression and activation of checkpoints) on multiple levels $[75,76]$.
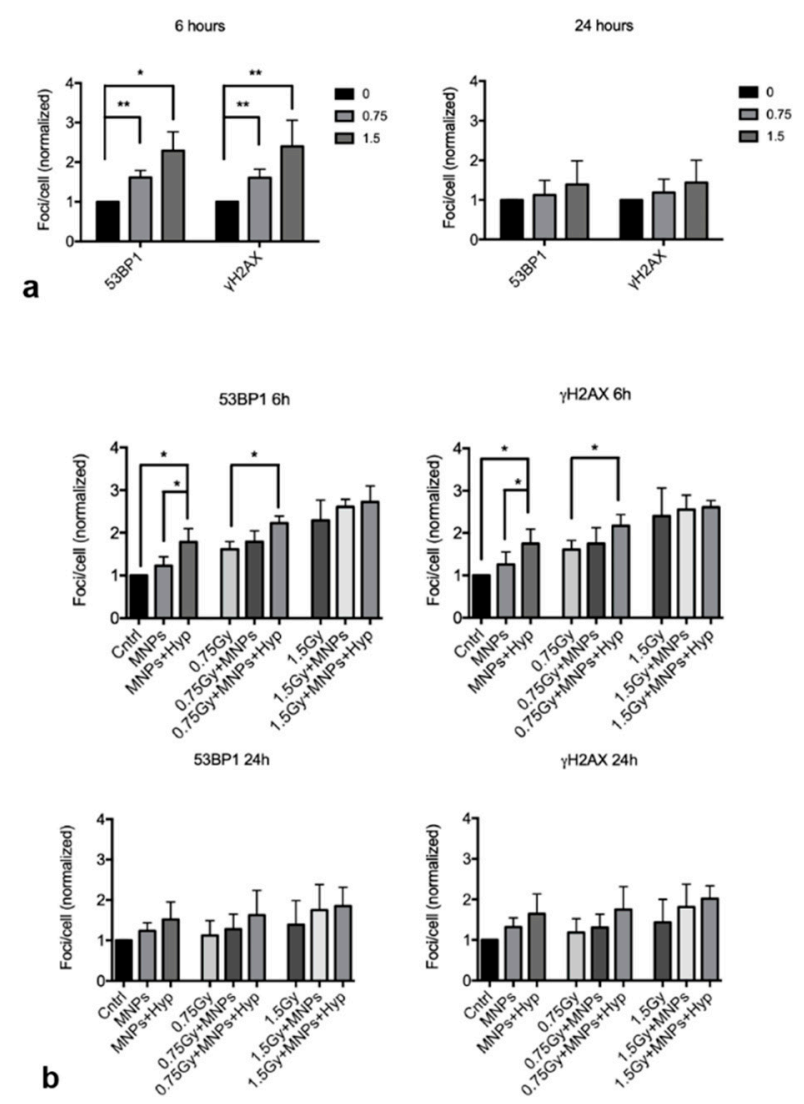

Figure 6. Analysis of 53BP1 and $\gamma \mathrm{H} 2 \mathrm{AX}$ foci induction after 6 and $24 \mathrm{~h}$ from the exposure to 0.75 and 1.5 Gy of carbon ions alone (a) and in combination with MNP uptake and/or Hyp in BxPC3 pancreatic tumor cells $(\mathbf{b}) .{ }^{*}$ indicates $p<0.05,{ }^{* *}$ indicates $p<0.01$ (one-way ANOVA and Tukey's multiple comparison post-test).

\section{Conclusions}

In this work, we reported on a combination of carbon ion therapy and hyperthermia applied to pancreatic adenocarcinoma cells $\mathrm{BxPC} 3$, for assessing its antitumor efficacy and proposing protocols for future clinical applications. The results obtained were compared to those achieved with a $6 \mathrm{MV}$ photon beam irradiation joint to hyperthermia. A significant part of the heating power was provided through MFH ( $40 \%$ of the total heating), assisted by magnetite nanoparticles with a core diameter of $19 \mathrm{~nm}$ and coated with an organic biocompatible ligand, namely DMSA. The hadron carbon ion therapy was shown to have $\mathrm{RBE} \sim 3.5$, thus confirming a greater efficacy with respect to photon therapy. The clonogenic survival results with respect to a simple irradiation of culture cells, clearly show: (i) at all HT/photon irradiation doses, a further killing (toxicity) additive effect of about $50-60 \%$ due to the MNPs cellular uptake and (ii) a significant killing effect of hyperthermia, consisting in an additive 15-30\% of total CS, for both irradiation protocols (MNPs action possibly being synergistic 
when radiation therapy is delivered by photons). Moreover, a significant increase of DNA-DSBs was observed at $6 \mathrm{~h}$ after $0.75 \mathrm{~Gy}$-dose HT irradiation plus administered MNPs and Hyp, with respect to the sample exposed to irradiation only.

The increased efficacy of hadron therapy combined with hyperthermia (applied immediately after) lays the foundations for future preclinical studies. Furthermore, these encouraging results point in the direction of further investigating this combination, with a view to finally translate it to a clinical application.

Supplementary Materials: The following are available online at http:/www.mdpi.com/2079-4991/10/10/1919/s1, Figure S1: XRD pattern, Figure S2: Zeta potential measurements, Figure S3: SAR estimation method, Tables S1 and S2: determination of optimal time of MNPs uptake and concentration, Table S3: BxPC3 cell cycle analysis after $48 \mathrm{~h}$ of treatment with MNPs, Table S4: cellular uptake of MNPs evaluation, Figure S4: dissolution experiments by the radiotracing method.

Author Contributions: F.B. (Francesca Brero), M.A. (Martin Albino), A.A., P.A., M.A. (Matteo Avolio), F.B. (Francesco Berardinelli), D.B., P.C., M.C. (Maurizio Corti), S.G., F.G., A.G., C.I., C.L., S.L., S.M., M.M., F.O., C.S., I.V. and A.L. conceived, designed and performed the experiments; F.B. (Francesca Brero), M.A. (Martin Albino), A.A., P.A., M.A. (Matteo Avolio), F.B. (Francesco Berardinelli), D.B., P.C., F.G., A.G., C.I., C.L., S.M., R.M., F.O., C.S., I.V. and A.L. analyzed the data; F.B. (Francesca Brero) wrote the original draft; A.A., P.C., C.I., C.S., F.O., P.A. and A.L. revised and edited the original draft; E.P., M.C. (Mario Ciocca ), A.F. and A.L. supervised the project. All authors have read and agreed to the published version of the manuscript.

Funding: This research received no external funding.

Acknowledgments: The authors thank INFN HADROCOMBI and HADROMAG projects for funding the work, The COST Action TD1402 (RADIOMAG) and the COST Action EURELAX (EU CA15209) are also acknowledged. We are grateful to Marco Cobianchi for his help, especially in the first phase of the work regarding the implementation of the experimental set up. Acknowledgements are also due to A.P. Caricato, P. Cerello and V. Conte, for very useful discussions and suggestions.

Conflicts of Interest: The authors declare no conflict of interest.

\section{References}

1. Rawla, P.; Sunkara, T.; Gaduputi, V. Epidemiology of Pancreatic Cancer: Global Trends, Etiology and Risk Factors. World J. Oncol. 2019, 10, 10-27. [CrossRef]

2. De La Cruz, M.S.D.; Young, A.P.; Ruffin IV, M.T. Diagnosis and Management of Pancreatic Cancer. Am. Fam. Phys. 2014, 89, 626-632.

3. Rubin, P.; Constine, L.S.; Marks, L.B. ALERT-Adverse Late Effects of Cancer Treatment; Springer: Heidelberg, Germany, 2014.

4. Shinoto, M.; Shioyama, Y.; Matsunobu, A.; Okamoto, K.; Suefuji, H.; Toyama, S.; Honda, H.; Kudo, S. Dosimetric Analysis of Upper Gastrointestinal Ulcer after Carbon-Ion Radiotherapy for Pancreatic Cancer. Radiother. Oncol. 2016, 120, 140-144. [CrossRef]

5. Caivano, D.; Vitolo, V.; Fiore, M.R.; Iannalfi, A.; Vischioni, B.; Bonora, M.; D'ippolito, E.; Ronchi, S.; Molinelli, S.; Ciocca, M.; et al. EP-1421: Carbon Ions In The Treatment of Pancreatic Disease. Radiother. Oncol. 2018, 127, S773. [CrossRef]

6. Shinoto, M.; Yamada, S.; Terashima, K.; Yasuda, S.; Shioyama, Y.; Honda, H.; Kamada, T.; Tsujii, H.; Saisho, H.; Asano, T.; et al. Carbon Ion Radiation Therapy with Concurrent Gemcitabine for Patients with Locally Advanced Pancreatic Cancer. Int. J. Radiat. Oncol. Biol. Phys. 2016, 95, 498-504. [CrossRef]

7. NIH, U.S. National Library of Medicine. Available online: https:/clinicaltrials.gov/ct2/show/NCT00685763; https:/clinicaltrials.gov/ct2/show/NCT03885284; (accessed on 31 May 2020).

8. Nichols, R.C. Proton Therapy for Pancreatic Cancer. World J. Gastrointest. Oncol. 2015, 7, 141. [CrossRef]

9. Kim, T.H.; Lee, W.J.; Woo, S.M.; Kim, H.; Oh, E.S.; Lee, J.H.; Han, S.S.; Park, S.J.; Suh, Y.G.; Moon, S.H.; et al. Effectiveness and Safety of Simultaneous Integrated Boost-Proton Beam Therapy for Localized Pancreatic Cancer. Technol. Cancer Res. Treat. 2018, 17. [CrossRef]

10. Available online: www.fondazionecnao.it (accessed on 11 May 2020).

11. Spirou, S.V.; Costa Lima, S.A.; Bouziotis, P.; Vranješ-Djurić, S.; Efthimiadou, E.K.; Laurenzana, A.; Barbosa, A.I.; Garcia-Alonso, I.; Jones, C.; Jankovic, D.; et al. Recommendations for In Vitro and In Vivo Testing of Magnetic Nanoparticle Hyperthermia Combined with Radiation Therapy. Nanomaterials 2018, 8, 306. [CrossRef] 
12. Spirou, S.V.; Basini, M.; Lascialfari, A.; Sangregorio, C.; Innocenti, C. Magnetic Hyperthermia and Radiation Therapy: Radiobiological Principles and Current Practice †. Nanomaterials 2018, 8, 401. [CrossRef]

13. Datta, N.R.; Ordóñez, S.G.; Gaipl, U.S.; Paulides, M.M.; Crezee, H.; Gellermann, J.; Marder, D.; Puric, E.; Bodis, S. Local hyperthermia combined with radiotherapy and-/or chemotherapy: Recent advances and promises for the future. Cancer Treat Rev. 2015, 41, 742-753. [CrossRef]

14. Dharmaiah, S.; Zeng, J.; Rao, V.S.; Ouyang, Z.; Ma, T.; Yu, K.; Bhatt, H.; Shah, C.; Godley, A.; Xia, P.; et al. Clinical and dosimetric evaluation of recurrent breast cancer patients treated with hyperthermia and radiation. Int. J. Hyperth. 2019, 36, 985-991. [CrossRef]

15. Elming, P.B.; Sørensen, B.S.; Oei, A.L.; Franken, N.A.; Crezee, J.; Overgaard, J.; Horsman, M.R. Hyperthermia: The optimal treatment to overcome radiation resistant hypoxia. Cancers 2019, 11, 60. [CrossRef]

16. van der Zee, J. Heating the Patient: A Promising Approach? Ann. Oncol. 2002, 13, 1173-1184. [CrossRef]

17. Baronzio, G.F.; Hager, E.D. Hyperthermia in Cancer Treatment: A Primer; Springer Science \& Business Media: Berlin/Heidelberg, Germany, 2006.

18. Overgaard, J. Simultaneous and Sequential Hyperthermia and Radiation Treatment of an Experimental Tumor and Its Surrounding Normal Tissue in Vivo. Int. J. Radiat. Oncol. Biol. Phys. 1980, 6, 1507-1517. [CrossRef]

19. Lin, J.C.; Lin, M.F. Microwave Hyperthermia-Induced Blood-Brain Barrier Alterations. Radiat. Res. 1982, 89, 77-87. [CrossRef]

20. Prasad, B.; Kim, S.; Cho, W.; Kim, J.K.; Kim, Y.A.; Kim, S.; Wu, H.G. Quantitative Estimation of the Equivalent Radiation Dose Escalation Using Radiofrequency Hyperthermia in Mouse Xenograft Models of Human Lung Cancer. Sci. Rep. 2019, 9, 3942. [CrossRef]

21. Mari, A.D.I.; Giuliano, S.R.; Lanteri, E.; Pumo, V.; Romano, F.; Trombatore, G.; Bucolo, A.; Tralongo, P. Clinical use of high- intensity focused ultra- sound in the management of different solid tumors. WCRJ 2014, 1, e295.

22. Liang, X.; Gao, J.; Jiang, L.; Luo, J.; Jing, L.; Li, X.; Jin, Y.; Dai, Z. Nanohybrid Liposomal Cerasomes with Good Physiological Stability and Rapid Temperature Responsiveness for High Intensity Focused Ultrasound Triggered Local Chemotherapy of Cancer. ACS Nano 2015, 9, 1280-1293. [CrossRef]

23. Abe, M.; Hiraoka, M.; Takahashi, M.; Egawa, S.; Matsuda, C.; Onoyama, Y.; Morita, K.; Kakehi, M.; Sugahara, T. Multi-institutional Studies on Hyperthermia Using an 8-MHz Radiofrequency Capacitive Heating Device (Thermotron RF-8) in Combination with Radiation for Cancer Therapy. Cancer 1986, 58, 1589-1595. [CrossRef]

24. Müller, G.J.; Roggan, A. (Eds.) Laser-Induced Interstitial Thermotherapy; SPIE Press: Bellingham, WA, USA, 1995.

25. Guardia, P.; Di Corato, R.; Lartigue, L.; Wilhelm, C.; Espinosa, A.; Garcia-Hernandez, M.; Gazeau, F.; Manna, L.; Pellegrino, T. Water-Soluble Iron Oxide Nanocubes with High Values of Specific Absorption Rate for Cancer Cell Hyperthermia Treatment. ACS Nano 2012, 6, 3080-3091. [CrossRef]

26. Ortega, D.; Pankhurst, Q.A. Magnetic Hyperthermia. Nanoscience 2013, 1, e88.

27. Périgo, E.A.; Hemery, G.; Sandre, O.; Ortega, D.; Garaio, E.; Plazaola, F.; Teran, F.J. Fundamentals and Advances in Magnetic Hyperthermia. Appl. Phys. Rev. 2015, 2, 041302. [CrossRef]

28. Tay, Z.W.; Chandrasekharan, P.; Chiu-Lam, A.; Hensley, D.W.; Dhavalikar, R.; Zhou, X.Y.; Yu, E.Y.; Goodwill, P.W.; Zheng, B.; Rinaldi, C.; et al. Magnetic Particle Imaging-Guided Heating in Vivo Using Gradient Fields for Arbitrary Localization of Magnetic Hyperthermia Therapy. ACS Nano 2018, 12, 3699-3713. [CrossRef]

29. Cabrera, D.; Coene, A.; Leliaert, J.; Artés-Ibáñez, E.J.; Dupré, L.; Telling, N.D.; Teran, F.J. Dynamical Magnetic Response of Iron Oxide Nanoparticles Inside Live Cells. ACS Nano 2018, 12, 2741-2752. [CrossRef]

30. Pan, J.; Hu, P.; Guo, Y.; Hao, J.; Ni, D.; Xu, Y.; Bao, Q.; Yao, H.; Wei, C.; Wu, Q.; et al. Combined Magnetic Hyperthermia and Immune Therapy for Primary and Metastatic Tumor Treatments. ACS Nano 2020, 14, 1033-1044. [CrossRef]

31. Niculaes, D.; Lak, A.; Anyfantis, G.C.; Marras, S.; Laslett, O.; Avugadda, S.K.; Cassani, M.; Serantes, D.; Hovorka, O.; Chantrell, R.; et al. Asymmetric Assembling of Iron Oxide Nanocubes for Improving Magnetic Hyperthermia Performance. ACS Nano 2017, 11, 12121-12133. [CrossRef]

32. Espinosa, A.; Di Corato, R.; Kolosnjaj-Tabi, J.; Flaud, P.; Pellegrino, T.; Wilhelm, C. Duality of Iron Oxide Nanoparticles in Cancer Therapy: Amplification of Heating Efficiency by Magnetic Hyperthermia and Photothermal Bimodal Treatment. ACS Nano 2016, 10, 2436-2446. [CrossRef]

33. Xu, C.; Zheng, Y.; Gao, W.; Xu, J.; Zuo, G.; Chen, Y.; Zhao, M.; Li, J.; Song, J.; Zhang, N.; et al. Magnetic Hyperthermia Ablation of Tumors Using Injectable Fe3O4/Calcium Phosphate Cement. ACS Appl. Mater. Interfaces 2015, 7, 13866-13875. [CrossRef] 
34. El Hajj Diab, D.; Clerc, P.; Serhan, N.; Fourmy, D.; Gigoux, V. Combined Treatments of Magnetic Intra-Lysosomal Hyperthermia with Doxorubicin Promotes Synergistic Anti-Tumoral Activity. Nanomaterials 2018, 8, 468. [CrossRef]

35. Kaczmarek, K.; Hornowski, T.; Antal, I.; Rajnak, M.; Timko, M.; Józefczak, A. Sono-magnetic heating in tumor phantom. J. Magn. Magn. Mater. 2020, 500, 166396. [CrossRef]

36. Curcio, A.; Silva, A.; Cabana, S.; Espinosa, A.; Baptiste, B.; Menguy, N.; Wilhelm, C.; Abou-Hassan, A. Iron Oxide Nanoflowers @ CuS Hybrids for Cancer Tri-Therapy: Interplay of Photothermal Therapy, Magnetic Hyperthermia and Photodynamic Therapy. Theranostics 2019, 9, 1288-1302. [CrossRef] [PubMed]

37. Peeken, J.C.; Vaupel, P.; Combs, S.E. Integrating Hyperthermia into Modern Radiation Oncology: What Evidence Is Necessary? Front. Oncol. 2017, 7, 132. [CrossRef] [PubMed]

38. Datta, N.R.; Krishnan, S.; Speiser, D.E.; Neufeld, E.; Kuster, N.; Bodis, S.; Hofmann, H. Magnetic Nanoparticle-Induced Hyperthermia with Appropriate Payloads: Paul Ehrlich's "Magic (Nano)Bullet" for Cancer Theranostics? Cancer Treat. Rev. 2016, 50, 217-227. [CrossRef] [PubMed]

39. Brezovich, I.A. Low Frequency Hyperthermia: Capacitive and Ferromagnetic Thermoseed Methods. In Medical Physics Monograph No 16: Biological, Physical, and Clinical Aspects of Hyperthermia; American Institute of Physics: University Park, MD, USA, 1988.

40. Johannsen, M.; Jordan, A.; Scholz, R.; Koch, M.; Lein, M.; Deger, S.; Roigas, J.; Jung, K.; Loening, S. Evaluation of Magnetic Fluid Hyperthermia in a Standard Rat Model of Prostate Cancer. J. Endourol. 2004, 18, 495-500. [CrossRef]

41. Johannsen, M.; Thiesen, B.; Jordan, A.; Taymoorian, K.; Gneveckow, U.; Waldöfner, N.; Scholz, R.; Koch, M.; Lein, M.; Jung, K.; et al. Magnetic Fluid Hyperthermia (MFH) Reduces Prostate Cancer Growth in the Orthotopic Dunning R3327 Rat Model. Prostate 2005, 64, 283-292. [CrossRef]

42. Jordan, A.; Scholz, R.; Wust, P.; Fähling, H.; Krause, J.; Wlodarczyk, W.; Sander, B.; Vogl, T.; Felix, R. Effects of Magnetic Fluid Hyperthermia (MFH) on C3H Mammary Carcinoma in Vivo. Int. J. Hyperth. 1997, 13, 587-605. [CrossRef]

43. Available online: www.magforce.com (accessed on 31 August 2020).

44. Jordan, A.; Scholz, R.; Maier-Hauff, K.; Johannsen, M.; Wust, P.; Nadobny, J.; Schirra, H.; Schmidt, H.; Deger, S.; Loening, S.; et al. Presentation of a new magnetic field therapy system for the treatment of human solid tumors with magnetic fluid hyperthermia. J. Magn. Magn. Mater. 2001, 225, 118-126. [CrossRef]

45. Jordan, A.; Scholz, R.; Wust, P.; Fähling, H.; Roland, F. Magnetic fluid hyperthermia (MFH): Cancer treatment with AC magnetic field induced excitation of biocompatible superparamagnetic nanoparticles. J. Magn. Magn. Mater. 1999, 201, 413-419. [CrossRef]

46. Maier-Hauff, K.; Rothe, R.; Scholz, R.; Gneveckow, U.; Wust, P.; Thiesen, B.; Feussner, A.; von Deimling, A.; Waldoefner, N.; Felix, R.; et al. Intracranial thermotherapy using magnetic nanoparticles combined with external beam radiotherapy: Results of a feasibility study on patients with glioblastoma multiforme. J. Neuro-Oncol. 2007, 81, 53-60. [CrossRef]

47. Johannsen, M.; Thiesen, B.; Wust, P.; Jordan, A. Magnetic nanoparticle hyperthermia for prostate cancer. Int. J. Hyperth. 2010, 26, 790-795. [CrossRef]

48. Maier-Hauff, K.; Ulrich, F.; Nestler, D.; Niehoff, H.; Wust, P.; Thiesen, B.; Orawa, H.; Budach, V.; Jordan, A. Efficacy and Safety of Intratumoral Thermotherapy Using Magnetic Iron-Oxide Nanoparticles Combined with External Beam Radiotherapy on Patients with Recurrent Glioblastoma Multiforme. J. Neurooncol. 2011, 103, 317-324. [CrossRef]

49. de Rego, G.N.A.; Mamani, J.B.; Souza, T.K.F.; Nucci, M.P.; da Silva, H.R.; Gamarra, L.F. Therapeutic Evaluation of Magnetic Hyperthermia Using $\mathrm{Fe}_{3} \mathrm{O}_{4}$-Aminosilane-Coated Iron Oxide Nanoparticles in Glioblastoma Animal Model. Einstein (Sao Paulo) 2019, 17. [CrossRef] [PubMed]

50. Mannucci, S.; Ghin, L.; Conti, G.; Tambalo, S.; Lascialfari, A.; Orlando, T.; Benati, D.; Bernardi, P.; Betterle, N.; Bassi, R.; et al. Magnetic Nanoparticles from Magnetospirillum Gryphiswaldense Increase the Efficacy of Thermotherapy in a Model of Colon Carcinoma. PLoS ONE 2014, 9, e0108959. [CrossRef] [PubMed]

51. Dutz, S.; Hergt, R. Magnetic Particle Hyperthermia—A Promising Tumour Therapy? Nanotechnology 2014, 25, 452001. [CrossRef] [PubMed]

52. Alphandéry, E.; Faure, S.; Seksek, O.; Guyot, F.; Chebbi, I. Chains of Magnetosomes Extracted from AMB-1 Magnetotactic Bacteria for Application in Alternative Magnetic Field Cancer Therapy. ACS Nano 2011, 5 , 6279-6296. [CrossRef] 
53. Jordan, A.; Wust, P.; Scholz, R.; Tesche, B.; Fähling, H.; Mitrovics, T.; Vogl, T.; Cervós-Navarro, J.; Felix, R. Cellular Uptake of Magnetic Fluid Particles and Their Effects on Human Adenocarcinoma Cells Exposed to AC Magnetic Fields in Vitro. Int. J. Hyperth. 1996, 12, 705-722. [CrossRef]

54. Oh, Y.; Lee, N.; Kang, H.W.; Oh, J. In Vitro Study on Apoptotic Cell Death by Effective Magnetic Hyperthermia with Chitosan-Coated MnFe2O4. Nanotechnology 2016, 27, 115101. [CrossRef]

55. Datta, N.R.; Schneider, R.; Puric, E.; Ahlhelm, F.J.; Marder, D.; Bodis, S.; Weber, D.C. Proton Irradiation with Hyperthermia in Unresectable Soft Tissue Sarcoma. Int. J. Part. Ther. 2016, 3, 327-336. [CrossRef]

56. Maeda, J.; Fujii, Y.; Fujisawa, H.; Hirakawa, H.; Cartwright, I.M.; Uesaka, M.; Kitamura, H.; Fujimori, A.; Kato, T.A. Hyperthermia-Induced Radiosensitization in CHO Wild-Type, NHEJ Repair Mutant and HR Repair Mutant Following Proton and Carbon-Ion Exposure. Oncol. Lett. 2015, 10, 2828-2834. [CrossRef]

57. Ahmad, S.; Jin, H.; Sahoo, K.; Griffin, R.J.; Herman, T.S.; Ranjan, A. Proton Therapy in Combination With Mild Hyperthermia Enhances Killing of Radio-Resistant Hypoxic Tumor Cells. Int. J. Radiat. Oncol. 2017, 99, E574. [CrossRef]

58. Dong, S.; Chen, Y.; Yu, L.; Lin, K.; Wang, X. Magnetic Hyperthermia-Synergistic $\mathrm{H}_{2} \mathrm{O}_{2}$ Self-Sufficient Catalytic Suppression of Osteosarcoma with Enhanced Bone-Regeneration Bioactivity by 3D-Printing Composite Scaffolds. Adv. Funct. Mater. 2020, 30, 1907071. [CrossRef]

59. Ito, A.; Kuga, Y.; Honda, H.; Kikkawa, H.; Horiuchi, A.; Watanabe, Y.; Kobayashi, T. Magnetite Nanoparticle-Loaded Anti-HER2 Immunoliposomes for Combination of Antibody Therapy with Hyperthermia. Cancer Lett. 2004, 212, 167-175. [CrossRef] [PubMed]

60. Cervadoro, A.; Giverso, C.; Pande, R.; Sarangi, S.; Preziosi, L.; Wosik, J.; Brazdeikis, A.; Decuzzi, P. Design Maps for the Hyperthermic Treatment of Tumors with Superparamagnetic Nanoparticles. PLoS ONE 2013, 8, e57332. [CrossRef] [PubMed]

61. Soeya, S.; Hayakawa, J.; Takahashi, H.; Ito, K.; Yamamoto, C.; Kida, A.; Asano, H.; Matsui, M. Development of Half-Metallic Ultrathin Fe3O4 Films for Spin-Transport Devices. Appl. Phys. Lett. 2002, 80, 823-825. [CrossRef]

62. Hall, E.J.; Giaccia, A.J. (Eds.) Radiobiology for the Radiologist, 6th ed.; Lippincott Williams \& Wilkins: Philadelphia, PA, USA, 2006.

63. Habermehl, D.; Ilicic, K.; Dehne, S.; Rieken, S.; Orschiedt, L.; Brons, S.; Haberer, T.; Weber, K.J.; Debus, J.; Combs, S.E. The Relative Biological Effectiveness for Carbon and Oxygen Ion Beams Using the Raster-Scanning Technique in Hepatocellular Carcinoma Cell Lines. PLoS ONE 2014, 9, e113591. [CrossRef] [PubMed]

64. Combs, S.E.; Zipp, L.; Rieken, S.; Habermehl, D.; Brons, S.; Winter, M.; Haberer, T.; Debus, J.; Weber, K.J. In Vitro Evaluation of Photon and Carbon Ion Radiotherapy in Combination with Chemotherapy in Glioblastoma Cells. Radiat. Oncol. 2012, 7, 1-6. [CrossRef] [PubMed]

65. Cui, X.; Oonishi, K.; Tsujii, H.; Yasuda, T.; Matsumoto, Y.; Furusawa, Y.; Akashi, M.; Kamada, T.; Okayasu, R. Effects of Carbon Ion Beam on Putative Colon Cancer Stem Cells and Its Comparison with X-Rays. Cancer Res. 2011, 71, 3676-3687. [CrossRef]

66. El Shafie, R.A.; Habermehl, D.; Rieken, S.; Mairani, A.; Orschiedt, L.; Brons, S.; Haberer, T.; Weber, K.J.; Debus, J.; Combs, S.E. In Vitro Evaluation of Photon and Raster-Scanned Carbon Ion Radiotherapy in Combination with Gemcitabine in Pancreatic Cancer Cell Lines. J. Radiat. Res. 2013, 54 (Suppl. 1), i113-i119. [CrossRef]

67. Oonishi, K.; Cui, X.; Hirakawa, H.; Fujimori, A.; Kamijo, T.; Yamada, S.; Yokosuka, O.; Kamada, T. Different Effects of Carbon Ion Beams and X-Rays on Clonogenic Survival and DNA Repair in Human Pancreatic Cancer Stem-like Cells. Radiother. Oncol. 2012, 105, 258-265. [CrossRef]

68. Li, M.; Zhao, Q.; Yi, X.; Zhong, X.; Song, G.; Chai, Z.; Liu, Z.; Yang, K. Au@MnS@ZnS Core Shell/Shell Nanoparticles for Magnetic Resonance Imaging and Enhanced Cancer Radiation Therapy. ACS Appl. Mater. Interfaces 2016, 8, 9557-9564. [CrossRef]

69. Liu, C.J.; Wang, C.H.; Chen, S.T.; Chen, H.H.; Leng, W.H.; Chien, C.C.; Wang, C.L.; Kempson, I.M.; Hwu, Y.; Lai, T.C.; et al. Enhancement of Cell Radiation Sensitivity by Pegylated Gold Nanoparticles. Phys. Med. Biol. 2010, 55, 931. [CrossRef] [PubMed]

70. Wang, X.; Zhang, C.; Du, J.; Dong, X.; Jian, S.; Yan, L.; Gu, Z.; Zhao, Y. Enhanced Generation of Non-Oxygen Dependent Free Radicals by Schottky-Type Heterostructures of $\mathrm{Au}-\mathrm{Bi}_{2} \mathrm{~S}_{3}$ Nanoparticles via X-Ray-Induced Catalytic Reaction for Radiosensitization. ACS Nano 2019, 13, 5947-5958. [CrossRef] [PubMed]

71. Goel, S.; Ni, D.; Cai, W. Harnessing the Power of Nanotechnology for Enhanced Radiation Therapy. ACS Nano 2017, 11, 5233-5237. [CrossRef] [PubMed] 
72. Rogakou, E.P.; Boon, C.; Redon, C.; Bonner, W.M. Megabase Chromatin Domains Involved in DNA Double-Strand Breaks in Vivo. J. Cell Biol. 1999, 146, 905-916. [CrossRef]

73. Schultz, L.B.; Chehab, N.H.; Malikzay, A.; Halazonetis, T.D. P53 Binding Protein 1 (53BP1) Is an Early Participant in the Cellular Response to DNA Double-Strand Breaks. J. Cell Biol. 2000, 151, 1381-1390. [CrossRef]

74. Ma, J.; Zhang, Z.; Zhang, Z.; Huang, J.; Qin, Y.; Li, X.; Liu, H.; Yang, K.; Wu, G. Magnetic Nanoparticle Clusters Radiosensitise Human Nasopharyngeal and Lung Cancer Cells after Alternating Magnetic Field Treatment. Int. J. Hyperth. 2015, 31, 800-812. [CrossRef]

75. Oei, A.L.; Vriend, L.E.; Crezee, J.; Franken, N.A.; Krawczyk, P.M. Effects of hyperthermia on DNA repair pathways: One treatment to inhibit them all. Radiat. Oncol. 2015, 10,1-13. [CrossRef]

76. Oei, A.L.; Kok, H.P.; Oei, S.B.; Horsman, M.R.; Stalpers, L.J.A.; Franken, N.A.P.; Crezee, J. Molecular and biological rationale of hyperthermia as radio- and chemosensitizer. Adv. Drug Deliv. Rev. 2020. [CrossRef]

(C) 2020 by the authors. Licensee MDPI, Basel, Switzerland. This article is an open access article distributed under the terms and conditions of the Creative Commons Attribution (CC BY) license (http://creativecommons.org/licenses/by/4.0/). 